\title{
Influential factors on students' vocational aspiration in Turkish elementary schools
}

\author{
Fulya Damla Kentli \\ Department of Elementary Education, Yildiz Technical University, School of Education, A-1026, 34210- \\ Davutpasa/Istanbul, Turkey.
}

Accepted 18 December, 2013

\begin{abstract}
This study explored the fifth grade elementary school students' vocational aspiration and the factors affecting it. The sample consisted of 115 students in 20 elementary public schools with whom face-toface interviews were conducted. The findings showed that engineering, medical doctor, and school teachers were the most frequently mentioned three vocations to which students aspired. Boys were found to aspire to traditionally-masculine occupations; girls aspired to traditionally-female occupations. Parents seemed to be the most influential factor on students' vocational aspiration, followed by the favorite academic subject and social environment. On the other hand, vocational guidance activities were the least influential factor, which was not a surprise given that approximately $90 \%$ of the students indicated absence of vocational guidance activities. Based on the findings, improving the quality and quantity of the vocational guidance activities at schools is suggested.
\end{abstract}

Key words: Elementary school, vocational aspiration, student.

\section{INTRODUCTION}

Individuals from the earliest of their life often come across with the question what they want to be when they grow up. Early vocational developmental theorists explicitly have affirmed that childhood is a vital formative period for vocational development (Ginzberg et al., 1951; Havighurst, 1972; Roe, 1956). Studies have shown that numbers of factors are associated with children's vocational choice development. Among them are parents, the favorite academic subject, social environment and planned or unplanned vocational guidance activities at schools.

Children's vocational aspiration development starts as early as at preschool years. In those early years, parents play a critical role in motivating and encouraging their children to explore about various vocations (Seligman et al., 1988). In their study, Seligman et al. (1988) found that children tend to acquire more information about their parents' vocation if their parents have a positive attitude towards it. Another way that parents influence children's vocational aspiration, as found in a study by Helwig (1998), is that parents somehow express their expectations from their children about which vocation they (children) should have and children pursue their vocational aspiration to meet their parents' expectations. Parents' gender is also another influential factor in children's vocational aspirations. Trice and Knapp (1992) found that children have learned more about their mothers' vocation than about fathers' vocation.

When children start elementary school their perceptions towards academic subjects initiate, which, as recognized by several authors (Atkinson, 1964; Weiner, 1974) might be linked to their vocational aspiration. Eccles et al. (1983) pointed out that achievement-related beliefs, outcomes, and goals might influence one's future 
vocational aspiration. For example, Hollinger (1983) found a relationship between gifted girls' math ability and their aspirations to enter math-related vocations, such as engineering and computer science. Moreover, Betz and Hackett (1986) pointed out that there is a link between ratings of personal efficacy in various academic subjects and vocational aspiration. Eccles et al. (1998) dealt with the gender issue in tendency of relation between academic subjects and vocational aspiration. They found that girls rated themselves as having better abilities in English, health and social studies, but weaker abilities in math and science subjects than boys did.

Several researchers have shown that social environment is associated with children's vocational aspirations. Reviewing an extensive body of research, Watson and McMahon (2005) concluded that children learn about the vocations by interacting with their social environment. Societal norms shape perceptions about a vocation, for example whether it is prestigious, or it is an occupation that boys or girls should do, which forms a gender stereotyping in children's vocational aspirations. The gender stereotyping seems to appear particularly at early ages and traditional role models and limited information about the occupations leads children to develop such a tendency. As societal norms transform to non-traditional role models, the gender stereotyping may also change. For example, in Turkey while nurses or primary school teachers were mostly females, with the increases in the male nurses (or making them more visible) and primary school teachers, there seems to be more boys who consider those vocations as possible ones for themselves.

The role of media cannot be ignored in acquiring information about various occupational types and in shaping individual's perceptions. In their daily life, children experience limited number of real representations of any vocational type. For example, a child may be exposed to teachers daily, but they see a doctor or nurse if they need a health care, or see a traffic police if they travel. Thus, many of the vocations are underrepresented in their daily life. Media, particularly television, provides a bunch of vocations with good and bad examples and with traditional and non-traditional role models. Though children reported that TV has a little influence on their vocational aspiration (McMahon et al., 2001), children probably absorb some information and develop perceptions implicitly.

A number of studies have suggested that vocational guidance is required to inform early vocational perception and help children to develop a meaningful understanding of relevance of school based learning to their future (Super, 1990; Gottfredson, 1996; Kepceoglu, 1992; Herr and Cramer, 1996; Schultheiss, 2005). Vocational guidance activities can be utilized through classroom guidance lessons and group work. Students in primary grades can also be introduced to vocabulary designed to clarify the concept of postsecondary training in relation to careers and self. As young children fantasize about careers or college, the school counselor can introduce curriculum activities that weave together fantasy and realistic postsecondary education and vocations. These activities may aid students in recognizing training or education needs (Trice and McClellan, 1993). Vocational programming improves students' self-concept, social skills, decision-making skills and academic achievement (Isaacson and Brown, 1997).

The literature on vocational development of children throughout elementary school shows that following the vocational education and vocational guidance in schools, the students can list the vocations and categorize their favorites. Comprehensive career programs provided by school counselors are an investment primarily of time (Niles and Stamp, 1998). Literature (Kuzgun, 2006; Bacanli, 2012) suggests that school counselors should accept fantasy vocational aspiration as future possibilities, while at the same time furnishing realistic information about vocations. As students begin to restrict their aspirations based on increased understanding of their abilities and interests, their aspirations can be channeled in new directions involving alternative vocations and training.

In Turkey, vocational guidance activities in elementary school are employed by guidance teachers within the regulation of the National Ministry of Education. According to the issue of Article 8, guidance and psychological counseling services in each school are responsible for performing vocational guidance activities, which introduce and inform about various vocations, by which students are encouraged to explore the possible occupations for their future (Mevzuat, 2009).

Although Turkish educational laws regulated the vocational guidance activities at schools, whether students experience such activities at their school and whether those activities inspire them for their future vocations are not clear. In addition, potential factors influencing vocational aspiration are identified by the international research. However, there is a gap in the literature at the national level in Turkey. This study aims to fill this gap and proposes to identify potential influential factors in elementary students' vocational aspiration. Therefore, the current study proposed to answer the following research questions: Which vocation(s) do boys and girls aspire for the future? What/Who are the influential factors in student' vocational aspiration?

\section{METHOD}

\section{Participants}

The participants of this study consisted of 115 (48 boys and 57 girls) fifth grade elementary school students during 2011-2012 spring semester in 20 public schools located in different areas of Istanbul. Students were in classrooms where 23 pre-service teachers who were in their last semester at the university and enrolled in a guidance course did their teaching practicum. In each 
Table 1. Frequency distribution in percentages: classifications of vocational aspirations by gender.

\begin{tabular}{lcccccc}
\hline Vocational Aspirations & $\begin{array}{c}\text { Boys } \\
\text { (n=48) }\end{array}$ & \multicolumn{2}{c}{$\begin{array}{c}\text { Girls } \\
(\mathbf{n}=\mathbf{5 7})\end{array}$} & \multicolumn{2}{c}{ Total } \\
$(\mathbf{n}=\mathbf{1 1 5})$
\end{tabular}

classroom, five students with high grades were purposefully selected for the study.

\section{PROCEDURE}

Permission from school principals was gained. Parents also agreed for the interview. In order to protect the confidentiality of participants, students' names were changed to A, B, C... Then, 23 pre-service teachers were trained on the research procedure.

This research applied a one-on-one structured interview procedure. The structured interview questions addressed the possible factors that influence children's vocational aspiration. The first two questions were open-ended, which were:

(1) Which vocation do you aspire for the future?

(2) Who/What did you get affected most? This question was followed up by sub-questions to investigate whether the study data would reveal the specific factors identified in the literature. Those questions were:

(2a) Did your parents intervene with this decision?

(2b) Which course do you like most? Why?

(2c) Was there any vocational guidance activity in your school? Do you think it has influenced your decision? What kind of guidance activities did your guidance teacher implement?

School canteens were arranged for the interviews. Each interview lasted approximately $30 \mathrm{~min}$ to complete. All interviews were completed in 20 days.

\section{Data analyses}

Each interview was transferred to MAXqda software program (2012) for the content analysis. The coding procedure was started with empty list. Initially, 10 interviews were examined by two coders independently. Each coder identified eight categories. Then, they discussed the categories and definitions and agreed upon the categories. Afterwards, each coder analyzed the rest of the data independently.

\section{RESULTS}

\section{Students' future vocational aspiration}

Table 1 illustrates the ratings of vocational aspirations by gender. As seen in the table, boys and girls seem to have similar aspirations for some vocations, while they show the opposite tendency for some. For example, medical doctor is the most-frequently mentioned vocation for girls $(22 \%)$ and second most frequently mentioned vocation for both boys (17\%). On the other hand, engineering is the most frequently mentioned vocation by boys $(25 \%)$, and one of the least frequently mentioned by girls $(3 \%)$. School teacher appeared to be the second most frequently mentioned vocation by girls (19\%), while it was one of the least mentioned vocations by boys (4\%). Glancing through the table, in general, except for medical doctor, which seems to be a non-gender stereotyped occupation, boys were found to aspire for traditionallymasculine occupations which are characterized by more physically active, concrete and practical occupations (e.g., engineer, sport). On the other hand, girls aspired for traditionally-female occupations which are characterized by more people-related, artistic and data-based occupations (e.g. school teacher, medical professions. and artist).

\section{Specific factors for elementary students' vocational aspiration}

To answer the question of "who/what affected your vocational aspiration most" the students were free to list more than one factor that they thought influential on their vocational aspiration. In addition, the answers to the subquestions (whether their parents, and favorite subject and vocational guidance activities at school were influential on their vocational aspiration) were integrated to the analyses. A preadolescent would say "yes" to as many sub-questions (e.g., whether his parent intervenes with his vocational aspiration) as he/she wants if he/she thought they were influential as shown in Table 2.

As seen in Table 2, 111 students mentioned parents. 93 students mentioned favorite academic subject, 55 students mentioned social environment and 35 students mentioned vocational guidance activity at the school as influential factors on their vocational aspiration. Boys and girls seem to show similar trend in getting influenced by those four factors. Next, how those factors influenced their vocational aspiration were analyzed qualitatively.

\section{Parental influence}

Two subcategories of parental influence were identified: Direct influence and role modeling. Direct influence referred to whether father or mother directly intervenes in 
Table 2. Frequency distribution of students: classifications of affirmed influenced categories by gender.

\begin{tabular}{lccc}
\hline & \multicolumn{3}{c}{ Number of Students } \\
\hline Influential Factors & $\begin{array}{c}\text { Boys } \\
(\mathbf{n = 4 8 )}\end{array}$ & $\begin{array}{c}\text { Girls } \\
\mathbf{( 5 7 )}\end{array}$ & $\begin{array}{c}\text { TOTAL } \\
(\mathbf{n}=\mathbf{1 1 5})\end{array}$ \\
\hline & $\mathbf{F}$ & $\mathbf{F}$ & $\mathbf{F}$ \\
\hline Parental Influence & 48 & 53 & 111 \\
Favourite Academic Subject & 43 & 50 & 93 \\
Social Environment & 27 & 28 & 55 \\
Vocational Guidance Activities & 15 & 20 & 35 \\
\hline
\end{tabular}

the vocational aspiration of students through direct expressions of approvals, encouragements or discouragement about which vocations their children should have or have not in the future. Some examples were:

They want me to become architecture. It doesn't matter for me since I like painting. Particularly, my mom insists me on choosing to become architecture. $(A)$

My mom told me that I should become a medical doctor. Then, I decided to be a medical doctor. (B)

My parents encourage me to become a policeman. Because they think that my physical appearance is good enough for such a vocation. (C)

Well, my parents never intervene with my decisions. I would like to a policeman. When I said this aspiration to my parents, they questioned it and told me to look for another vocation. (D)

My dad wishes that I would become a lawyer. He also encourages me to become a math teacher since it is my fun. (E)

Role model referred to the statements where the students express that they take their mother or father as a model in their decision making for their vocation. Some expressions coded under this category were:

My mom is medical doctor and my dad is a dentist. I admire both of them since they help and heal people. It is a really nice work. And I would like to become a doctor like them. $(F)$

I always wish to become a nurse, because my mom is nurse. I often go to hospital with her and she helps people. I admire her. I would like to become a nurse like her. (G)

I often go to kinder garten with my mom since she works there and I like her job. And, I wish to become a kinder garten teacher like her. $(H)$

Both my grandfather and my dad are policeman. I admire them so I would like to become a policeman. (I)

\section{Favorite academic subject}

The responses were coded under the influence of favorite academic subject if student made a linkage between their vocational aspiration and favorite academic subject in the school.

I like math course and I would like to be an engineer. (J) I am good at science courses so I believe that I can become a doctor. (K)

I am good at painting in our visual art course and my teacher also likes it. That's why I want to become a designer. ( $L$ )

A notable vocational aspiration difference in student' favorite academic subject could be mentioned in terms of gender. For instance, $\mathrm{J}$ was a boy who wanted to be an engineer stating his decision due to fun of the course. What could be mentioned from this statement that this was a traditionally masculine stereotyped. $\mathrm{K}$ aspired for medical doctor and $L$ aspired for designer. They were both girls. From their statement, it could be inferred that their vocational aspirations were traditionally-female stereotyped.

\section{Social environment}

Two subgroups under this main category emerged: Influence of immediate social environment and influence of TV.

\section{Immediate social environment}

The responses including existence of real vocational role models other than parents (e.g., friends, relatives), support and encouragement from individuals in their social environment were categorized under this category. Some expressions were:

I want to be a lawyer for a long time. Everybody thinks that I have the ability to perform this vocation; I would like to choose it. (M)

I decided on this vocation a few years ago. I was affected by my parent's lawyer relatives and friends. They can defend both themselves and other people's rights. $(N)$ My mom's best friend is a prominent doctor and I admire her a lot. So, I want to become a doctor like her. (O)

\section{Influence of television}

Student statements about the characters, movies and programs that gave them vocational aspiration were coded under this category.

I want to be a football player because I'm fun of Ronaldo. I like watching football on TV. $(P)$

I notice on the TV. I have been considering for about two years. I took one of the advertisements as a model. I wish 
to construct buildings for those who need help when I become an architect. (Q)

I decided to become a policeman when I started to watch detective films on TV. (R)

\section{Vocational guidance activities}

Three subcategories of vocational guidance activities were identified: Classroom speakers, information on jobs and other. Classroom speakers referred to the students' expressions mentioning that professionals from various jobs were invited to their school to inform students about their jobs. Some examples are:

Yes, there is vocational guidance activity in our school. Sometimes, our classroom teachers invite experts in their occupations to give information about their field. I like this activity since it helps me to identify vocations. (S)

Our guidance teacher invited his friends from several different vocations. A police officer came in the police week; a fireman in the fireman week. $(T)$

\section{Information on jobs}

This category included guidance teacher giving specific information to the students about jobs.

Yes, there is a vocational guidance education in our school. Our class teacher listens to our opinions on vocations and she gives information on each job. I'm learning various vocations in this lesson. (U)

Our guidance teacher gives information on several vocations enabling us to be acknowledged with the function of the vocations. (V)

\section{Other activities}

Any other activities concerning vocational guidance such as going to the work places to have experience about the related work are coded under this category. Statements below are some examples of this category.

Our guidance teacher sometimes employs surveys on our vocational aspirations. She invites us one by one and makes small conversations. (W)

Each student in the classroom chose his/her future desired vocations and prepared homework and presented in the classroom. $(X)$

\section{Absence of vocational guidance activities at school}

On average, $90 \%$ of the students expressing that there was no vocational activity in the school were coded under this category.

No, I do not remember any. We do not have any vocational activities. ( $Y$ )

Well, I do not know any. (Z)

Responses made by some students implied not only absence of vocational guidance, but the reasons for not having such guidance and what guidance teachers focus on mostly; preventing or dealing with behavioral problems, and advising on being good children.

Actually, I can't remember any vocational activity that has impact on our vocational aspiration. I know just the name of my guidance teacher. Our classroom teacher asks several questions in our guidance lesson. She advises us to have good relations with our friends. She also advises us to respect our parents. (A1)

I do not have any problem to consult the guidance teacher in the school. Some of my friends are having problem, they often go there. (B1)

Our guidance teacher is mostly interested in those students having problems either with their parents or friends. I do not have any problems with my friends and parents so I never visit her office in the school. (C1)

One of my friends often visits our guidance teacher's office when she starts to cry. I think the teacher gives some advice there, because when she returns she stops crying. (D1)

\section{DISCUSSION}

This study investigated elementary students' vocational aspiration and self-stated factors that may influence their aspiration. Utilizing a one-on-one interview procedure with 115 fifth grade students, the findings of this study, in general showed consistent results with the previous studies.

This study pointed out that there was a gender difference in vocational aspiration of the students. In consistent with the previous studies, in this study, boys were found to aspire for more physically active, concrete and practical occupations, while girls aspired for more people-related, artistic and data-based occupations (Phipps, 1995). Moreover, Bandura et al. (2001) stated that boys evidenced greater confidence in aspiring scientific and technological occupations, while girls evidenced more confidence in aspiring occupations in education, health and social services. The findings of this study revealed a parental influence on vocational aspiration of students. In agreement with previous research (Helwig, 1998; Emment and Preston, 2001) students in this study reported that parents have influence on their vocational aspiration directly by expressing what they expect their children to be, and affirming or disaffirming their children's vocational aspiration or indirectly by role modeling. 
The findings of this study indicate that there is a link between favorite academic subject and students' vocational aspiration in consistent with studies of both Hollinger (1983), Betz and Hackett (1986) Eccles et al. (1998). This study revealed that boys' math ability and their aspirations to enter math-related vocations, such as engineering and girls' (social) science ability enable them to enter (social) science-related vocations, such as medical doctor, teacher.

In agreement with previous research (McMahon et al., 2001), the findings showed that TV and students' immediate social environment are among the factors influencing their vocational aspiration. Individuals such as relatives and family friends who have various jobs and popular characters showing up on TV (e.g., football players) seem to affect students' vocational aspiration.

An important finding of this study is that although National Educational Ministry of Turkey (MEB) has regulations about implementing vocational guidance activities at schools, very few numbers of students reported the presence of such activities. Students' statements imply that guidance teachers at schools deal with almost everything, but vocational guidance. Given the importance of such activities in the early elementary grades in furnishing realistic information about vocations and their educational prerequisites (Kuzgun, 2006; Bacanli, 2012), several steps should be taken. First of all, the crucial role of vocational guidance activities during elementary school should be accepted to encourage students to explore their perceptions for their vocational aspiration. The second, vocational guidance activities in early elementary grades should be done more actively and effectively. To do so, guidance teachers' responsibilities, requirements, and accountabilities should be regulated. In addition, hindrances preventing guidance teachers to implement vocational guidance activities should be identified and resolved.

This study comes with several limitations. Firstly, the research was limited with the written statements of fifth grade elementary students in 20 public schools; hence it is not possible to generalize the findings. Secondly, merely, the responses of students were interpreted. Including class teachers and guidance teachers would facilitate understanding of the context from multiple perspectives.

\section{Conclusion}

Vocational choice is a developmental process starting with aspirations and exploration in the elementary school years. Moreover, students had a wide range of vocational maturity, interests, valu.es, and abilities. In this regard, students need a great variety of guidance activities and opportunities to explore their personal characteristics and vocational options. Therefore, classroom teacher and vocational guidance teacher should encourage students to explore feelings, needs, and uncertainties about their vocational aspiration in collaboration with their parents. Vocational activities throughout students' school life should be enriched, improved and enable students to be more aware of the vocational guidance activities.

\section{REFERENCES}

Atkinson JW (1964). An introduction to motivation. Princeton, NJ: Van Nostrad.

Bacanli F (2012). Kariyer karar verme güçlükleri ve meslek seçimine ilişkin akılcı olmayan inançların ilişkisi. Türk Psikolojik Danışma ve Rehberlik Dergisi. 4(37), 86-95.

Bandura A, Barbaranelli C, Caprara G, Pastorelli C (2001). Self-efficacy beliefs as shapers of children's aspirations and career trajectories. Child Dev. 72:187-206.

Betz NE, Hackett G (1986). Application of self-efficacy theory to understanding career choice behavior. J. Soc. Clin. Psychol. 4:279 289.

Eccles JS, Barber B, Jozefowicz D (1998). Linking gender to educational, occupational, and recreational choices: applying the Eccles et al. model of achievement-related choices. In Sexism and Stereotypes in Modern Society: The Gender Science of Janet Taylor Spence, ed. WB Swann, JH Langlois, LA Gilbert. Washington, DC: Am. Psychol. Assoc. pp.153-192.

Eccles JS, Adler TF, Futterman R, Goff SB, Kaczala CM, Meece JL (1983). Expectancies, values, and academic behaviors. In J. T. Spence (Ed.), Achievement and achievement motivation. pp.75-146. San Francisco, CA: W. H. Freeman.

Emmentt J, Preston D (2001). Career Development in the Elementary School in Sandhu. Daya Singh Ed. Elementary School Counseling in the Millennium. Chapter 7. American Counseling Association, Alexandria, VA.

Ginzberg E, Ginsburg S W, Axelrad S, Herma JL (1951). Occupational choice: An approach to general theory. New York: Columbia University Press.

Gottfredson LS (1996). Gottfredson's theory of circumscription and compromise. In D Brown, L Brooks (Eds), Career choice and development, San Francisco, Jossey-Bass. pp.179-232

Havighurst R (1972). Developmental tasks and education. Longman, New York.

Helwig AA (1998). Developmental and sex differences in workers' functions of occupational aspirations of a longitudinal sample of elementary school children. Psychol. Rep. 82:915-921.

Herr EL, Cramer SH (1996). Career guidance and counseling through the life span: Systematic approaches. New York, Longman.

Hollinger CL (1983). Self-perception and the career aspirations of mathematically talented female adolescents. J. Vocat. Behav. 22:49 62.

Isaacson LE, Brown D (1997). Career information, career counseling, and career development. Needham Haights, MA: Ally \& Bacon.

Kepceoglu M (1992). Psikolojik Danisma ve Rehberlik. Ankara Yayinevi.

Kuzgun Y (2006). Meslek rehberligi ve danismanligina giris. Ankara: Nobel Yayin Dagitim.

MAXqda (2012). Software for qualitative data analysis, 1989-2013, VERBI Software- Consult - Sozialforschung GmbH, Berlin, Germany.

McMahon M, Carroll J, Gillies RM (2001). Career dreams: Occupational aspirations of year six children. Aust. J. Career Dev. 10:25-31.

MEB (2009). MEB Mevzuat. Milli Eğitim Bakanligi İlkogretim Kurumlari Yönetmeliği, Ankara.

Niles SG, Stamp JA (1998). The school counselor's role in career development. In J Dykeman (eds) Maximizing school guidance program effectiveness: A guide for school administrators and program director. pp.81-86.

Phipps BJ (1995). Career dreams of preadolescent students. J. Career Dev. 22:19-32.

Roe A (1956). The psychology of careers. New York: Wiley.

Schultheiss DEP, Palma TV, Manzi AJ (2005). Career Development in Middle Childhood: A Qualitative Inquiry. Career Dev. Quat. 53:246262. 
Seligman L, Weinstock L, Owings N (1988). The role of family dynamics in career development of 5-year-olds. Elementary School Guidance and Counseling. 22:222-230.

Super DE (1990). A life-span, life space approach to career development. In D. Brown \& L. Brooks (eds) Career choice and development, pp 197-261. San Francisco, CA: Jossey-Bass.

Trice AD, Knapp L (1992). Relationship of children's career aspirations to parents' occupations. J. Genet. Psychol. 153:355-357.

Trice AD, McClellan N (1993). Do children's career aspirations predict adult occupations? An answer from a secondary analysis of a longitudinal study. Psychol. Reports. 72:368-370.
Watson M, McMahon M (2005). Children's Career Development: A research review from a learning perspective. J. Vocat. Behav. 67:119-132.

Weiner B (1974). Achievement motivation and attribution theory. Morristown, NJ: General Learning Press. 